\title{
Certezas Incertas: Desafios Próximos no Diagnóstico Laboratorial da COVID-19
}

\section{Uncertain Certainties: Upcoming Challenges in the Laboratory Diagnosis of COVID-19}

\author{
Pedro CABRAL ${ }^{1}$, Bernardo GOMES ${ }^{2,3}$, Mafalda FELGUEIRAS $\square^{1}$ \\ Acta Med Port 2021 Jan;34(1):3-5 - https://doi.org/10.20344/amp.15002
}

Palavras-chave: COVID-19; SARS-CoV-2; Técnicas de Laboratório Clínico; Testes Imediatos

Keywords: Clinical Laboratory Techniques; COVID-19; Point-of-Care Testing; SARS-CoV-2

Vivemos hoje na iminência de um dos invernos mais desafiantes para os sistemas de saúde mundiais. A atual pandemia da COVID-19 veio precipitar a necessidade de desenhar estratégias rápidas e eficazes no diagnóstico de infeções respiratórias. De acordo com a Organização Mundial da Saúde (OMS), o Coronavírus da síndrome respiratória aguda grave 2 (SARS-CoV-2), a 3 de outubro de 2020 , era já responsável por 34495176 contágios e 1025729 vítimas mortais. Antes deste, já as infeções víricas do trato respiratório eram anualmente responsáveis por morbimortalidade significativa em todo o mundo. ${ }^{1}$

O SARS-CoV-2 é um vírus de RNA, que apresenta a estrutura típica dos betacoronavírus, com um genoma que inclui duas regiões não traduzidas (5' e 3'), uma região conservada (ORF1ab) e quatro genes $\mathrm{S}, \mathrm{E}, \mathrm{M}$ e $\mathrm{N}$, que codificam as proteínas estruturais spike, envelope, membrane e nucleocapsid, respetivamente. Após divulgada a sequenciação do vírus, foram desenvolvidos primers dirigidos a estas regiões, passando a ser possível a amplificação de ácidos nucleicos (AAN), para detetar RNA viral em amostras clínicas. A RT-PCR (real-time reverse transcription polymerase chain reaction) é hoje a metodologia de eleição, dada a sua simplicidade, procedimentos estandardizados e ampla validação. ${ }^{2}$ Os critérios moleculares de positividade são no entanto heterogéneos, com os ensaios desenvolvidos e comercializados a amplificar em simultâneo diferentes genes/regiões do genoma viral. ${ }^{2,3}$ Esta heterogeneidade, a que se junta a ausência de um reconhecido gold standard comparativo para o diagnóstico da COVID-19, tornam difícil a avaliação da precisão destes testes. ${ }^{4}$ Neste âmbito, destacamos um estudo prospetivo que acompanhou 4950 contactos próximos de casos positivos na China, definindo uma sensibilidade de $71,9 \%$ e uma especificidade de $100 \%$ para um primeiro teste, bem como uma revisão sistemática que incluiu 957 doentes e reportou até 29\% de falsos-negativos num primeiro teste, o que traduz uma sensibilidade mínima de $71 \%{ }^{3,5} \mathrm{Um}$ resultado falso-negativo pode ser condicionado pelo tipo de amostra colhida, pela qualidade da colheita, pela carga viral na amostra, pela adequação do armazenamento e transporte, bem como pelas condições de testagem laboratorial.

Em Portugal, a RT-PCR começou por ser realizada em centros de referência, passando rapidamente a estar disponível numa maioria dos laboratórios hospitalares. Esta metodologia requer o processamento da amostra, com extração do RNA, e a subsequente amplificação do material genético, podendo levar até 3-4 horas a disponibilizar um resultado. Como noutras infeções por vírus respiratórios, onde o diagnóstico molecular é relevante, rapidamente foram desenvolvidos "testes rápidos" de RT-PCR, como é exemplo o Xpert $^{\circledR}$ Xpress SARS-CoV-2 (Cepheid $\left.{ }^{\circledR}\right) .{ }^{1}$ Consideradas metodologias point-of-care (POC), o processamento é simples, com resultados disponibilizados em cerca de 45 minutos. ${ }^{1}$ As vantagens em contexto hospitalar são inúmeras, permitindo o célere despiste de casos suspeitos, bem como o isolamento de contacto precoce de casos positivos, agilizando medidas de controlo de infeção. No entanto, a interpretação de um resultado depende não só das características do teste, mas também da probabilidade pré-teste da doença. ${ }^{4}$ Com elevadas especificidades, mas assumindo sensibilidades mínimas de $\approx 70 \%$ nos testes de Biologia Molecular, um resultado positivo é certamente útil, mas um resultado negativo deverá ser cuidadosamente interpretado. Dada a probabilidade de um resultado falso-negativo, é lícito manter precauções de contacto, ou ponderar a retestagem, em casos de elevada suspeita clínica ou epidemiológica. ${ }^{4}$

Para o diagnóstico da COVID-19, os testes de AAN utilizam habitualmente amostras obtidas do trato respiratório, colhidas com recurso a zaragatoas nasofaríngeas. ${ }^{4}$ As amostras de saliva têm vindo a ser apontadas como uma alternativa promissora, com um método de colheita simples e menos invasivo. No entanto, as discrepâncias encontradas em estudos comparativos, põem em evidência a necessidade de realizar estudos mais robustos, que permitam retirar conclusões firmes, estando de momento múltiplos ensaios clínicos em curso. ${ }^{6}$

\footnotetext{
1. Serviço de Patologia Clínica. Centro Hospitalar Universitário Cova da Beira. Covilhã. Portugal.

2. Unidade de Saúde Pública Entre Douro e Vouga I. Departamento de Saúde Pública Administração Regional da Saúde Norte. Porto. Portugal.

3. Instituto de Saúde Pública. Universidade do Porto. Porto. Portugal.

$\triangle$ Autor correspondente: Mafalda Felgueiras.mfelgueiras@gmail.com

Recebido: 29 de setembro de 2020 - Aceite: 29 de setembro de 2020 | Copyright $\odot$ Ordem dos Médicos 2021
} 
Na gestão da pandemia, os ensaios serológicos surgiram como metodologias complementares, com potencial de detetar contactos prévios com o vírus, mas também de serem integradas num rastreio rápido e em larga escala de indivíduos suspeitos, ou com infeções subclínicas. ${ }^{7}$ São já comercializados diferentes ensaios que avaliam a seroconversão na COVID-19, sendo as principais metodologias disponíveis em autoanalisadores a imunoabsorção enzimática (ELISA), os imunoensaios por quimioluminescência (CLIA) e os ensaios de fluorescência enzimáticos (ELFA). Capazes de avaliar um grande volume de amostras em simultâneo, disponibilizam resultados em 20 a 30 minutos, variando a imunoglobulina (lg) doseada (IgM, IgG, $\operatorname{lgA}$, combinação $\operatorname{lgM} / \operatorname{lgG}) .{ }^{7}$ Têm também a vantagem de ultrapassar algumas limitações pré-analíticas das técnicas moleculares, onde a qualidade da amostra depende da quantidade de genoma viral recolhido. Em função do momento fisiológico, pode assim perder-se a janela de replicação do vírus. ${ }^{7,8} A$ utilização de testes serológicos é por isso proposta, quer em combinação com o diagnóstico molecular, com potencial de aumentar a taxa de deteção da doença, quer para testagens suplementares em casos suspeitos com AAN negativa. Será importante ressalvar que alguns doentes, em função de comorbilidades ou intervenções terapêuticas, poderão não desenvolver resposta humoral. ${ }^{8}$ Num estudo onde é avaliado o desempenho de quatro ensaios serológicos automatizados na deteção de anticorpos anti-SARS-CoV-2, em 111 doentes com RT-PCR positiva, foram reportadas sensibilidades entre os $64,9 \%$ e os $82,9 \%$, bem como especificidades entre os $95,8 \%$ e os $100 \%$, dependendo do ensaio e das imunoglobulinas detetadas. ${ }^{7}$ Outro trabalho documentou um aumento da sensibilidade diagnóstica quando à PCR se acrescentou um doseamento de IgM por ELISA. O doseamento desta Ig, cujos níveis aumentaram globalmente até ao $14^{\circ}$ dia após o início dos sintomas, foi assim proposto como adjuvante ao diagnóstico molecular, aumentando a taxa de deteção da doença. ${ }^{8}$ No entanto, dadas as contradições encontradas na literatura relativamente aos perfis de seroconversão na COVID-19, ensaios combinados IgM/lgG poderão cumprir melhor essa finalidade. ${ }^{7}$

Atualmente, os hospitais portugueses têm montadas estratégias diagnósticas para identificar indivíduos com infeção por SARS-CoV-2 com alguma rapidez e precisão. Contudo, o inverno irá trazer a inevitável necessidade de realizar diagnósticos diferenciais com outros agentes de infeção respiratória, com destaque para o vírus influenza. ${ }^{1}$ Para além disso, existe a possibilidade de coinfeção na COVID-19, apontada pelos estudos como associada a doença mais severa e a uma maior mortalidade. ${ }^{9}$ Neste contexto, estão disponíveis testes POC multiplex automatizados, capazes de detetar simultaneamente vários agentes de infeção numa mesma amostra, incluindo vírus e bactérias. ${ }^{1}$ Brevemente, estarão também disponíveis no mercado novos ensaios POC moleculares, para identificação simultânea dos vírus influenza A, B e SARS-CoV-2.

De entre os testes POC, os imunocromatográficos para a deteção de antigénios têm ganho um recente protagonismo. No entanto, esta tipologia de testes apresenta diferentes limitações, que condicionam sensibilidades a variar entre os $53 \%$ e os $100 \%$, impossibilitando também testagens multiplex. ${ }^{1}$ Para além disso, a sua janela de utilização poderá ser muito limitada, pois os vírus respiratórios são melhor detetados após o início dos sintomas, com maior shedding viral nas primeiras $48-72$ horas em adultos. ${ }^{1} \mathrm{Im}$ porta relevar que ao abandonarem o contexto laboratorial, os testes POC não estão sujeitos aos mesmos requisitos de qualidade impostos pela certificação em laboratórios clínicos. Por outro lado, os fabricantes não estão obrigados a monitorizar e/ou melhorar o desempenho dos seus testes diagnósticos, que pode piorar ao longo do tempo, devido a divergências antigénicas ou genotípicas em vírus estabelecidos. É por isso importante que laboratórios de referência avaliem continuamente o desempenho dos testes POC, notificando fabricantes e entidades decisoras, quando detetado um declínio da sua performance. ${ }^{1}$

Estaremos preparados para o próximo inverno? É necessário que os hospitais, à luz dos seus recursos, definam estratégias para uma marcha diagnóstica eficaz, que acautele diagnósticos diferenciais, bem como a possibilidade de coinfeções. Havendo um aumento exponencial do número de casos, a utilidade dos testes POC moleculares será limitada pela incapacidade de se poder testar um elevado número de amostras em simultâneo. Assim, será inevitável continuar a recorrer à AAN convencional como principal método diagnóstico, o que levará inevitavelmente a tempos de resposta superiores. Neste cenário, importa referir que a maioria dos hospitais que tem implementadas metodologias diagnósticas para a COVID-19, encontra-se sobrecarregada com a testagem de amostras provenientes da comunidade, nomeadamente rastreios de contacto. Com o escalar da pandemia, será fundamental alocar estes testes a entidades terceiras, libertando os laboratórios hospitalares para a testagem de doentes a precisar de cuidados imediatos. No contexto da comunidade, os testes POC imunocromatográficos são uma alternativa promissora, passíveis de ser utilizados "no terreno", não só em surtos institucionais, como em avaliações regulares em lares, unidades de cuidados continuados, centros de dia e escolas. Estes testes, dada a facilidade de acesso e o menor custo económico, com prejuízo de sensibilidades e especificidades ótimas, adquirem um papel complementar e não substitutivo. ${ }^{10}$

Uma correta aplicação dos recursos de testagem é um dos pilares fundamentais para uma quasi-normalidade em tempos de COVID-19. Pela pressão da inovação, terá de ser revisitada regularmente nos meses vindouros.

\section{CONFLITOS DE INTERESSE}

Os autores não têm quaisquer conflitos de interesse.

\section{FONTES DE FINANCIAMENTO}

Não foi necessário financiamento por entidades externas. 


\section{REFERÊNCIAS}

1. Basile K, Kok J, Dwyer D. Point-of-care diagnostics for respiratory viral infections. Expert Rev Mol Diagn. 2018;18:75-83.

2. Yan Y, Chang L, Wang L. Laboratory testing of SARS-CoV, MERSCoV, and SARS-CoV-2 (2019-nCoV): Current status, challenges, and countermeasures. Rev Med Virol. 2020;30:e2106.

3. Arevalo-Rodriguez I, Buitrago-Garcia D, Simancas-Racines D, Zambrano-Achig P, del Campo R, Ciapponi A, et al. False-negative results of initial RT-PCR assays for COVID-19: a systematic review. MedRxiv. 2020. doi: 10.1101/2020.04.16.20066787.

4. Watson J, Whiting P, Brush J. Interpreting a covid-19 test result. BMJ. 2020;369:m1808.

5. Luo L, Liu D, Liao X, Wu X, Jing Q, Zheng J, et al. Modes of contact and risk of transmission in COVID-19 among close contacts. MedRxiv. 2020. doi: 10.1101/2020.03.24.20042606.

6. Czumbel L, Kiss S, Farkas N, Mandel I, Hegyi A, Nagy A. et al. Saliva as a candidate for COVID-19 diagnostic testing: a meta-analysis. Front Med. 2020;7:465.

7. Wolff F, Dahma H, Duterme C, Van den Wijngaert S, Vandenberg O, Cotton $\mathrm{F}$, et al. Monitoring antibody response following SARS-CoV-2 infection: diagnostic efficiency of 4 automated immunoassays. Diagn Microbiol Infect Dis. 2020;98:115140.

8. Guo L, Ren L, Yang S, Xiao M, Chang D, Yang F, et al. Profiling early humoral response to diagnose novel coronavirus disease (COVID-19). Clin Infect Dis. 2020;71:778-85.

9. Chen X, Liao B, Cheng L, Peng X, Xu X, Li Y, et al. The microbial coinfection in COVID-19. Appl Microbiol Biotechnol. 2020;104:7777-85.

10. Larremore D, Wilder B, Lester E, Shehata S, Burke J, Hay J, et al. Test sensitivity is secondary to frequency and turnaround time for COVID-19 surveillance. MedRxiv. 2020. doi: 10.1101/2020.06.22.20136309. 